\title{
Peranan Pemerintah Kota Padang Dalam Mengembangkan Batang Arau Sebagai Destinasi Wisata Kota Tua
}

\author{
Ade Nisrina ${ }^{1}$, Afriva Khaidir ${ }^{2}$ \\ 1,2Universitas Negeri Padang \\ Email: adenisrina77@gmail.com, af.khaidir@fis.unp.ac.id
}

\begin{abstract}
Abstrak
Kota Padang merupakan salah satu kota warisan Kolonial Belanda yang mempunyai daya tarik wisata jika dikembangkan dengan baik akan menjadi ikon wisata baru yang berbudaya dan bernilai sejarah. Kota tua seperti kota bersejarah lainnya di berbagai kota di negara-negara berkembang, pada umumnya dilestarikan bahkan menempati untuk meningkatkan nilai sejarah dan ekonomi. Nilai sejarah dan arsitektur dari Kota Tua Padang salah satunya di kawasan Batang Arau tidak kalah menarik dibandingkan dengan kota-kota lain. Namun demikian, kondisinya sekarang ini kurang termanfaat, bahkan bangunan sejarah kurang dimanfaatkan dan kurang terawat, selain itu daya tarik wisata seperti sungai Batang Arau kondisinya saat ini banyaknya sampah pelastik ditepi sungai, sehingga membuat Batang Arau terlihat kumuh dan kotor. Jadi Kota Tua telah menjadikan andalan sejarah objek tujuan wisata bagi Kota Padang dan memiliki potensi besar untuk membawa banyak wisatawan domestik dan asing. Penelitian ini bertujuan untuk mengetahui dan mendeskrisikan Peran Pemerintah Kota Padang Dalam mengmbangkan Batang Arau Sebagai Destinasi Wisata Kota Tua. Dalam penelitian ini metode yang digunakan adalah pendekatan kualitatif yang bersifat deskriptif. Sumber data dalam penelitian ini ada dua yaitu data primer dan data sekunder. Teknik pengumpulan data penelitian ini berupa observasi, wawancara dan dokumentasi. Hasil penelitian menunjukkan bahwa Pemerintah Kota Padang telah melakukan peranannya sesuai dengan tugas dan kewajiban satuan kerja perangkat daerah yaitu dengan melaksanakan peranan dalam melakukan perencanaan pariwisata, pembangunan pariwisata, kebijakan pariwisata dan peraturan pariwisata.
\end{abstract}

Kata kunci: Peranan Pemerintah, Pariwisata Perkotaan (Urban Tourism), Kota Tua Padang.

Padang City is one of heritage Netherlands Colonial cities that has tourism attraction if expanded perfectly will be a new cultural icon tourism and has history value. Others old history cities at the certain city in grown countries, generally eternalized even increasing history and economic value. One of History and architecture value from old Padang Cities located in Batang Arau area is interested as others interested city. Anyhow the previous condition and history building are not being functioned and maintained enough and the environment arround is not cleaned, there are a lots of plastic garbage in the riverside. The old city has been one of pledge tourism for Padang City and has big potensial to invite visitors from domestic or overseas. The purpose of this research is to know and describe the contribution of Padang Government in growing up Batang Arau as an old city destination. The method of this research is descriptive with quantitative approahead. The data are primary data and secondary data. The data are collected by observation, interview and documentation tehnique. The risults of this research showed that the Padang Government did their function as well based on the duty and responsibility by contributing in tourism planning, tourism planning development and tourism policy and regulation.

Keyword: Government Participation, Urban Tourism, Padang Old City 


\section{Pendahuluan}

Pariwisata merupakan salah satu sumber devisa negara yang mempunyai potensial dan andil besar dalam meningkatkan pertumbuhan perekonomian suatu Negara. Sektor pariwisata di Indonesia hal yang sangat mudah dikembangkan dengan melakukan perbaikan infrastuktur, keamanan dan management yang baik. Kebijakan pemerintah daerah dalam pembangunan pariwisata sangat penting perananya dalam menunjang keberhasilan pembangunan pariwisata nasional. (Rotua dan Rudi, 2016: 80). Linda Tondobala (2012: 89) mengemukakan bahwa pariwisata kota (urban tourism) yaitu suatu bentuk pengembangan pariwisata dengan lokasi wisata berada di dalam kota dimana area kota, elemen-elemen kota, bahkan kota itu sendiri menjadi suatu komoditas utama pariwisata.

Konsep pariwisata perkotaan berkembang seiring dengan perkembangan pariwisata perkotaan di seluruh dunia. Kota sejarah sebenarnya sudah mulai berkembang sejak abad ke16 (Ashworth dan Tunbridge, 1990), sedangkan konsep kota sejarah sebagai sumber daya pariwisata berkembang seiring dengan perkembangan pariwisata perkotaan (Ashworth dan Tunbridge, 1990). Konsep kota wisata sejarah merupakan konsep pariwisata perkotaan yang menjadikan peninggalan sejarah sebagai daya tarik wisatanya. Komponen-komponen dari kota wisata peninggalan sejarah ini antara lain lingkungan dengan arsitektur sejarah dan morfologi perkotaan, artefak budaya, serta keindahan artistik yang merupakan bahan baku dari konsep ini (Ashworth dan Tunbridge, 1990).

Kota Padang merupakan pintu gerbang dan pusat perdagangan bagi kawasan pedalaman sejak akhir abad ke-17. Pada wilayah administrasi kota Padang terdapat kota lama Padang yang merupakan wilayah yang dibangun oleh Belanda pada tahun 1799 sampai 1870 dengan tujuan menjadi kota pelabuhan yang memiliki aktivitas perdagangan secara global. Posisinya yang cukup strategis karena berada pada bagian tengah sisi barat pulau Sumatera (DPUPR, 2006: 9). Refni Yulia, dkk (2017: 18) menyatakan bahwa Padang merupakan salah satu kota warisan kolonial belanda yang mempunyai daya tarik wisata jika dikembangkan dengan baik akan menjadi ikon wisata baru yang berbudaya dan bernilai sejarah. Meri Erawati dalam Phill, dkk (2015: 153) mengungkapkan bahwa kota tua telah ditetapkan sebagai kawasan cagar budaya, dengan itu perlu dilestarikan keberadaannya karena memiliki nilai penting bagi sejarah, ilmu pengetahuan, pendidikan, agama, dan/atau kebudayaan melalui proses penetapan.

Guna mewujudkan pengembangan wisata Kota Tua Padang maka Pemerintah Kota Padang mengeluarkan Surat Keputusan Walikota Nomor 03 tahun 1998, menetapkan bangunan bersejarah berjumlah 74 bangunan, menetapkan 3 kawasan sejarah salah satunya yaitu kawasan Batang Arau. Batang Arau salah satu objek wisata alam dan wisata sejarah yang ada di kota Padang. Batang Arau terletak disebelah barat di muara sungai Batang Arau dan termaksud dalam Kelurahan Kampung Pondok, Kecamatan Padang Barat, Kota Padang. Batang Arau merupakan kawasan lama yang dahulunya menjadi pusat pemerintahan dan perdagangan bangsa Belanda. Pada kawasan inilah sebenarnya menjadi cikal bakal kota Padang yang sekarang ini. Disepanjang sungai Batang Arau hingga pelabuhan Muaro sejumlah bangunan tua menjadi saksi bisu jejak kolonial yang tertinggal.

Kawasan Batang Arau sudah ditetapkan sebagai wisata sejarah yang berfungsi untuk pariwisata, tentu akan meningkatkan pertumbuhan ekonomi masyarakat yang ada disekitarnya. Namun demikian, kondisinya saat ini kurang termanfaat. Keunikan dan kekhasan bangunan di kawasan Batang Arau memang menarik wisatawan berkunjung dan melihat-lihat, tetapi hal ini dapat dikatakan belum dikembangkannya secara optimal oleh pemerintah Kota Padang. selain itu masih banyak kendala yang dihadapi misalnya tidak adanya sarana dan prasarana seperti tidak adanya toilet di sepanjang kawasan Batang Arau, 
dan tidak tersedianya lahan parkir. Fasilitas pendukung destinasi wisata seperti transportasi umum memiliki peran penting bagi wisatawan agar dapat mengetahui jalan tercepat menuju tempat wisata, tetapi berdasarkan pengamatan penulis tidak adanya transportasi umum yang melewati kawasan Batang Arau. Kawasan Batang Arau banyak dilewati dengan transporasi pribadi.

Selain itu, kawasan Batang Arau memiliki daya tarik wisata lain yaitu sungai Batang Arau yang merupakan daerah aliran sungai (DAS). Sungai Batang Arau ini dahulunya menjadi tempat transportasi pada masa perdagangan kolonial Belanda, dan sekarang sungai Batang Arau dijadikan sebagai tempat parkirnya transportasi laut seperti kapal-kapal wisata ke mentawai dan ke pulau-pulau kecil yang terletak disebelah barat sungai Batang Arau dan di sebelah selatan terdapat kapal-kapal nelayan. Saat ini, sungai Batang Arau memiliki daya tarik wisata yang menghubungkan antara kota tua Padang dengan Gunung Padang. Berdasarkan pengamatan penulis permasalahan yang terdapat di sungai Batang Arau banyaknya terdapat sampah-sampah pelastik yang mengapung di sungai. Kemudian dengan keindahan kapal-kapal yang terparkir disekitaran Batang Arau menjadi daya tarik sungai tersebut, tetapi permasalahannya terlihat bahwa dermaga-dermaga kapal yang berada di kawasan Batang Arau itu tidak tersusun rapi bahkan banyaknya sampah yang bertebaran disekitar dermaga sehingga membuat dermaga yang berada ditepian sungai Batang Arau arah ke Kota Tua terlihat kumuh.

Penelitian ini bertujuan untuk mengetahui peranan pemerintah kota Padang dalam mengambangkan Batang Arau sebagai destinasi wisata kota tua. Dengan teori yang digunakan menurut Afandi (2017: 28) pemerintah memiliki peran dalam bidang pariwisata yaitu perencanaan pariwisata, pembangunan pariwisata, kebijakan pariwisata, dan peraturan pariwisata. Berdasarkan permasalahan diatas, bahwa Peraturan Walikota telah mengamangatkan pemerintah untuk melestarikan kawasan wisata sejarah, tetapi menurut penulis pemerintah belum optimal dalam mengambangkan Batang Arau sebagai destinasi wisata kota tua, maka penulis tertarik untuk melakukan penelitian yang berjudul "Peranan Pemerintah Kota Padang dalam mengembangan Batang Arau sebagai Destinasi Wisata Kota Tua".

\section{Metode Penelitian}

\section{Jenis Penelitian}

Penelitian ini merupakan penelitian kualitatif dengan metode deskriptif (Moleong, 2005: 4) karena peneliti akan mendeskripsikan Peranan Pemerintah Kota Padang dalam mengembangkan Batang Arau sebagai Destinasi Wisata Kota Tua pada aspek perencanaan pariwisata, pembangunan pariwisata, implementasi pariwisata, serta peraturan-peraturan pariwisata yang saat ini ada pada destinasi tersebut.

\section{Fokus Penelitian}

1. Peranan Pemerintah Kota Padang dalam mengembangkan Batang Arau sebagai destinasi wisata Kota Tua yang meliputi perencanaan oariwisata, pembangunan pariwisata, kebijakan pariwisata dan perturan pariwisata.

2. Faktor-faktor yang mempengaruhi pengembangan Batang Arau sebagai destinasi wisata Kota Tua.

3. Upaya dalam mengatasi faktor penghambat dalam mengembangkan Batang Arau sebagai destinasi wisata kota tua. 


\section{Lokasi penelitian}

Penelitian ini berlokasi di Kantor Dinas Kota Padang yaitu di Dinas Pariwisata dan Kebudayaan Kota Padang karena dinas yang bertanggung jawab dalam tujuan pariwisata yaitu Dinas Pariwisata dan Kebudayaan Kota Padang selain itu dinas tersebut yang dapat melestarikan serta menjaga kawasan kota tua untuk dapat dilestarikan.

\section{Teknik Pengumpulan Data}

Teknik pengumpulan data yang digunakan oleh peneliti adalah data primer diperoleh metode wawancara dengan sumber datanya adalah Kasi Cagar Budaya, Kabid Perencanaan dan program Dinas Pariwisata dan Kebudayaan Kota Padang, Kepala Dinas Badan Perencanaan Pembangunan Daerah, Kasi Perencanaan dan Program Dinas Pekerjaan Umum dan Penataan Ruang dan data sekunder diperoleh melalui dokumen-dokumen dan arsip yang diperoleh dari Dinas Pariwisata dan kebudayaan Kota Padang yang berkaitan dengan kota tua.

\section{Analisis dan Keabsahan Data}

Analisis data yang digunakan oleh peneliti adalah model sugiono. Menurut sugiono (2011:244) dalam penelitian kualitatif terdapat beberapa ativitas dalam menganalisis data berupa reduksi data, penyajian data, penarikan kesimpulan, dan verifikasi. Keabsahan data menggunakan teknik triangulasi Moleong, (2005:330).

\section{Hasil dan Pembahasan}

\section{Gambaran Umum Kota Padang}

Batang Arau salah satu objek wisata alam dan wisata sejarah yang ada di kota Padang. Batang Arau terletak disebelah barat di muara sungai Batang Arau dan termaksud dalam Kelurahan Batang Arau, Kecamatan Padang Selatan, Kota Padang. Batang Arau merupakan kawasan lama yang dahulunya menjadi pusat pemerintahan dan perdagangan bangsa Belanda. Pada kawasan inilah sebenarnya menjadi cikal bakal kota Padang yang sekarang ini. Disepanjang sungai Batang Arau hingga pelabuhan Muaro sejumlah bangunan tua menjadi saksi bisu jejak kolonial yang tertinggal. Dijalan ini berderet bangunan sejarah bekas kantor pemerintahan, perbankan, dan kantor dagang peninggalan VOC.

Berdasarkan data dari Badan Pusat Statistik Sumatera Barat, data tahun 2015 menunjukkan bahwa distribusi penduduk di Kecamatan Padang Selatan menurut kelurahan cukup bervasiasi, salah satunya yaitu kelurahan Batang Arau dengan luas 0,34 $\mathrm{km}^{2}$ dengan jumah penduduk 4.431 jiwa dengan kepadatan penduduk 13.032 jiwa. Penduduk menurut jenis kelamin, jumlah penduduk laki-laki di kelurahan Batang Arau tercatat sebanyak 2.223 orang sedangkan penduduk perempuan tercatat sebanyak 2.208 dengan sex ratio 100,68.

\section{Peranan Pemerintah Kota Padang dalam mengembangkan Batang Arau sebagai Destinasi Wisata Kota Tua}

\section{Kebijakan Pariwisata}

Kebijakan yang dibuat oleh Pemerintah Kota dalam mengembangkan Batang Arau berdasarkan Surat Keputusan Walikota Padang Nomor 154 tahun 2019 tentang tugas dan kewajiban satuan kerja perangkat daerah di kawasan Batang Arau. Kebijakan tersebut berisikan tugas dan kewajiban masing-masing Dinas dalam mengembangkan kawasan Batang Arau seperti tugas dan kewajiban Dinas Pariwisata dan kebudayaan kota Padang yaitu dengan melakukan sosialisasi sapta pesona, pembentukan kelompok atau pembinaan kelompok sadar 
wisata di Kawasan Batang Arau, selanjutnya Dinas Pekerjaan Umum dan Penataan Ruang bertugas dan berkewajiban penambhan penerangan jalan di beberapak titik di kawasan Batang Arau, dan perbaikan lampu jalan di beberapa titik sepanjang jalan Batang Arau. Selain itu kawasan Batang Arau merupakan kawasan dengan view bangunan sejarah atau cagar budaya serta suasana sungai, pantai dan gunung Padang. Dengan itu Pemerintah Kota Padang dalam melakukan pengembangan Batang Arau sebagai kawasan yang kaya dengan bangunan cagar budaya mengeluarkan kebijakan yaitu Peraturan Walikota Padang No 60 Tahun 2017 tentang pedoman penyelenggaraan cagar budaya. Kebijakan ini dibuat dengan tujuan mengamankan aset kekayaan budaya yang mempunyai nilai penting di daerah. implementasi dari kebijakan tersebut pemerintah kota Padang melakukan rangkaian kerja dengan penemuan bangunan sejarah, pendaftaran, penetapan dan pemeriksaan, pelestarian, pendanaan, pengawasan dan monitoring serta evaluasi.

\section{Peraturan Pariwisata}

Mengenai peraturan yang telah dibuat oleh Pemerintah Kota Padang yaitu Keputusan Walikota Padang nomor 60 tahun 2017 tentang pedoman penyelenggaraan cagar budaya, Disparbud hanya mengatur kebijakan dengan memberikan surat himbauan berkali-kali kepada pemilik bangunan cagar budaya. Selain itu dalam hal peraturan pariwisata di Batang Arau tidak ada aturan yang terkait dengan pariwisata di Batang Arau.

\section{Perencanaan Pariwisata}

a. Perencanaan Kawasan Wisata Terpadu (KWT)

Disparbud Kota Padang dalam melakukan sebuah perencanaan megembangan destinasi wisata Batang Arau tidak hanya sebatas dalam mempersiapkan sarana dan prasarana saja, akan tetapi juga melakukan perencanaan kawasan wisata terpadu. perencanaan membentuk suatu Kawasan Wisata Terpadu (KWT) yaitu kawasan yang dibangun khusus untuk tujuan pariwisata.

b. Perencanaan penambahan sarana dan prasarana wisata

Disparbud Kota Padang juga telah bekerjasama dengan Dinas PUPR Kota Padang dalam mengembangkan Batang arau sebagai destinasi wisata kota tua, Dinas PUPR memiliki rencana dalam meningkatkan daya tarik wisatawan berupa rencana pembangunan pendistrian berupa trotoar, dan lampu jalan di sekitaran Batang Arau. Dengan keberadaan dari pendistrian tersebut diharapkan dapat membentuk kawasan Batang Arau Kota Tua tersebut indah dengan dihiasi lampu-lampu taman khususnya pada malam hari sehingga dapat meningkatkan daya tarik bagi wisatawan dan juga masyarakat.

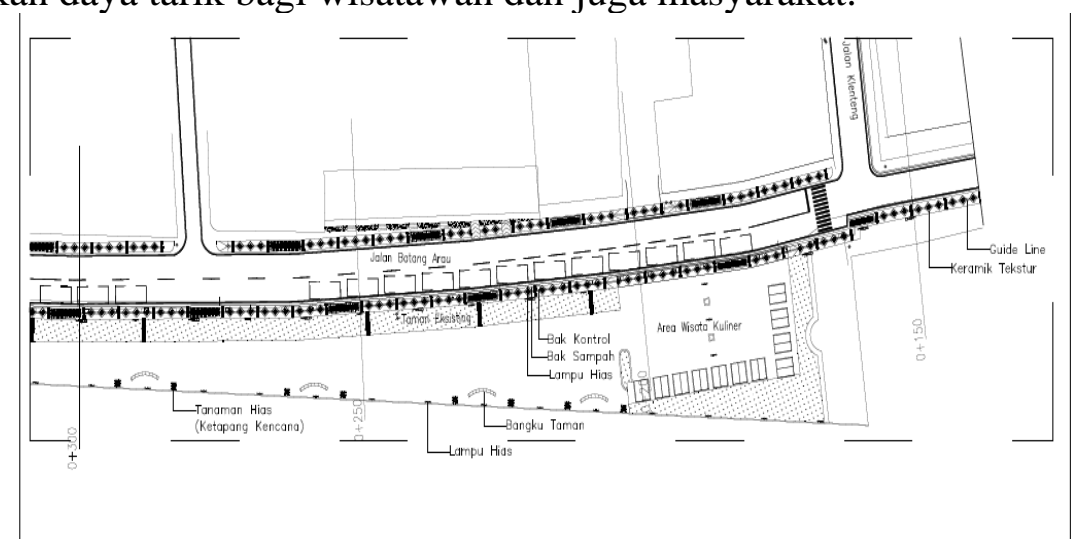

Gambar 1. Sarana dan Prasarana

Sumber: Dinas PUPR Kota Padang

Jurnal Perspektif Vol. 2, No. 2, Th. 2019 
c. Perencanaan pembuatan Pelabuhan Kapal Marina.

Pemerintah Kota Padang dalam melakukan pengembangan Batang Arau sebagai destinasi wisata kota tua berupa perencanaan pariwisata dalam meningkatkan daya tarik serta pembuatan pendistrian atau sarana dan prasarana pariwisata, dan juga perencanaan membuat pelabuhan kapal Marina di sungai Batang Arau. Tetapi masih dalam bentuk perencanaan, tidak ada dalam bentuk terlulis.

\section{Pembangunan Pariwisata}

Dinas Pariwisata dan Kebudayaan bekerjasama dengan Dinas Pekerjaan Umum Perumahan Rakyat sudah berupaya untuk mengembangkan Batang Arau melalui pembangunan sarana dan prasarana pariwisata. Pembangunan tersebut dinilai sudah cukup baik karena selain dapat digunakan wisatawan juga dapat dimanfaatkan oleh masyarakat sekitar destinasi wisata. Untuk melakukan pelestarian bangunan cagar budaya yang terdapat di Batang Arau Dinas Pariwisata dan Kebudayaan melakukan pembangunan dalam hal sosialisasi dengan tujuan untuk meningkatkan kesadaran masyarakat, atau pemilik bangunan, atau wisatawan sehingga memiliki pengetahuan akan pentingnya bangunan cagar budaya atau bangunan sejarah yang terdapat di kota tua kawasan Batang Arau tersebut. Berikut ini daftar bangunan Cagar Budaya yang ada di kawasan Batang Arau (Tabel 1).

\section{Tabel 1. Daftar Bangunan Cagar Budaya di Kawasan Batang Arau}

\begin{tabular}{clll}
\hline No. & Nama Bangunan (Lama) & \multicolumn{1}{c}{$\begin{array}{c}\text { Nama Bangunan } \\
\text { (Sekarang) }\end{array}$} & \multicolumn{1}{c}{ Kondisi Fisik } \\
\hline 1 & Kantor Geo Wehry \& CO & Gudang PT. Panca Niaga & Utuh dan terawat \\
\hline 2 & Gudang PT. Minang Caissa & $\begin{array}{l}\text { Gudang PT. Minang } \\
\text { Caissa }\end{array}$ & Utuh dan kurang terawat \\
\hline 3 & Kantor Bersumy Whry & Kantor PT/ Kerta Niaga & Utuh dan kurang terawat \\
\hline 4 & $\begin{array}{l}\text { Kantor Nederlandsch Indische } \\
\text { Escompto My }\end{array}$ & $\begin{array}{l}\text { Kantor Bank Dagang } \\
\text { Negara di Padang }\end{array}$ & Utuh dan terawat \\
\hline 5 & Spaar Bank & Penginapan & Utuh dan terawat \\
\hline 6 & Kantor PT Surya Sakti & Kantor PT. Surya Sakti & Utuh dan kurang terawat \\
\hline
\end{tabular}

Sumber: Dinas Pariwisata dan Kebudayaan Kota Padang

\section{Faktor-faktor yang mempengaruhi Batang Arau sebagai Destinasi Wisata Kota Tua Padang}

\section{Faktor Pendorong}

a. Daya tarik sejarah berupa bangunan sejarah masa Kolonial Belanda dengan menggambarkan keadaan Padang tempo dulu.

Berdasarkan tabel diatas Gedung Geo Wehry merupakan bangunan lama yang dahulunya didirikan oleh Pihak Belanda untuk dijadikan sebagai gudang. Secara keseluruhan bangunan ini terkesan tinggi dengan atap berbentuk segitiga yang meruncing ke atas secara 
frontal. Status kepemilikan dari gedung ini bersifat pribadi atau personal. Gedung Geo Wehry merupakan bangunan yang terdaftar dalam Keputusan Walikota Nomor 03 Tahun 1998 yang berisikan tentang kebijakan penetapan bangunan cagar budaya.

b. Kaindahan alam yang indah berupa Gunung Padang, jembatan Sitinurbaya, Bukit GadoGado, dan Sungai Batang Arau yang dilengkapi dengan kapal-kapal tradisional dan kapal wisata.

\section{Faktor Penghambat}

a. Ketersediaan anggaran

b. Ketersediaan sarana dan prasarana menjadikan ukuran optimal atau tidaknya pemerintah untuk melaksanakan tugas dan fungsinya sebagai pelayan masyarakat

c. Ketersediaan lahan parkir dan ketersediaan fasilitas umum seperti toilet.

d. Peran serta masyarakat berlum sepenuhnya mendukung program-program pemerintah.

\section{Upaya Pemerintah Kota Padang dalam mengembangkan Batang Arau sebagai destinasi wisata kota tua Padang.}

Adapun upaya yang dilakukan oleh Pemerintah Kota Padang khususnya Dinas Pariwisata dan Kebudayaan Kota Padang dalam mengatasi faktor penghambat dalam mengembangkan Batang Arau sebagai destinasi wisata kota tua yaitu dengan melakukan sosialisasi yang tujuannya untuk menambah pengetahuan masyarakat yang berada di objek wisata sehingga masyarakat akan sadar akan wisata yang terdapat di daerahnya.

Adapun sosialisasi yang dilakukan Dinas Pariwisata dan Kebudayaan Kota Padang di kawasan kota tua khususnya di Batang Arau, Dinas Pariwisata melalui Bidang Cagar Budaya membentuk Komunitas Padang Heritage yang bertujuan meningkatkan pengetahuan anak bangsa mengenai sejarah kota Padang, dengan adanya Komunitas Padang Heritage bisa nantinya mengajak masyarakat untuk sosialisasi mengenai pelestarian cagar budaya yang terdapat di kota tua Padang. Sosialisasi yang peneliti ikuti ketika hari Sumpah Pemuda tanggal 28 Oktober 2018 dengan tema Padang Heritage Walk Sosialisasi dan Pelestarian Kota Tua Padang. Terlihat pada gambar 5.

\section{Pembahasan}

\section{Peranan Pemerintah Kota Padang dalam mengembangkan Batang Arau sebagai Destinasi Wisata Kota Tua}

\section{Kebijakan Pariwisata}

Kebijakan pengembangan pariwisata memiliki manfaat jangka panjang, perencanaan serta pembangunan pada destinasi wisata harusnya mempunyai kebijakan sebagai acuannya (Afandi, 2017: 31). Dukungan dari Pemerintah Kota Padang juga akan mempengaruhi perkembangan kebijakan yang dilakukan dalam meningkatkan kualitas dan kuantitas pariwisata di daerah tersebut (Frinaldi, dkk, 2019: 50). Kebijakan dalam melakukan pengembangan Batang Arau sebagai wisata kota tua tertuang di dalam Keputusan Walikota Padang Nomor 154 Tahun 2019.

Prinsip kebijakan pariwisata sendiri seharusnya dapat menjamin negara maupun daerah untuk mendapatkan manfaat yang sebesar-besarnya dari kontribusi sosial dan ekonomi yang diberikan oleh pariwisata (Biederman dalam Afandi, 2017: 32). Kebijakan tersebut berisikan mengenai tugas dan kewajiban masing-masing Satuan Kerja Perangkat Daerah (SKPD) untuk dapat mengembangkan Batang Arau sebagai destinasi wisata. Dalam 
keputusan Walikota Padang No 154 Tahun 2019 menjelaskan ada 18 SKPD yang memiliki peranan dalam mengembangkan Kawasan Batang Arau. Salah satunya Disparbud dalam melakukan pengembangan Batang Arau sebagai destinasi wisata kota tua yaitu memiliki kebijakan dalam meningkatkan ekonomi untuk kesejahteraan masyarakat. Salah satu arah kebijakaan yang dilakukan oleh Disparbud di implementasikan ke dalam sebuah pengembangan daya tarik wisata sehingga mampu mendatangkan banyak wisatawan dan membuka mata pencaharian baru bagi masyarakat sekitar destinasi wisata kota tua. Peran SKPD dari Dinas PUPR dalam pengimplementasian kebijakan tersebut salah satunya yaitu melalui pembangunan infrastruktur yang ada di Batang Arau. Infrastruktur tersebut berupa pengadaan jalan, trotoar dan penyediaan lahan untuk pedagang kaki lima.

Selain itu kawasan Batang Arau merupakan kawasan dengan view bangunan sejarah atau cagar budaya serta suasana sungai, pantai dan gunung Padang. Dengan itu Pemerintah Kota Padang dalam melakukan pengembangan Batang Arau sebagai kawasan yang kaya dengan bangunan cagar budaya mengeluarkan kebijakan yaitu Peraturan Walikota Padang No 60 Tahun 2017 tentang pedoman penyelenggaraan cagar budaya. Kebijakan ini dibuat dengan tujuan mengamankan aset kekayaan budaya yang mempunyai nilai penting di daerah. implementasi dari kebijakan tersebut Disparbud melakukan rangkaian kerja yang terdapat pada Pasal 4 dengan menentukan kriteria cagar budaya, penemuan bangunan sejarah, pendaftaran, penetapan dan pemeriksaan, pelestarian, pendanaan, pengawasan, dan monitoring serta evaluasi.

\section{Peraturan Pariwisata}

Kegiatan atau aktifitas pada sebuah destinasi wisata diperlukan adanya peraturan yang berguna untuk kelancaran dan dapat mengurangi terjadinya pelanggaran yang dapat memberikan dampak buruk terhadap masyarakat maupun stakeholder yang ada pada destinasi wisata tersebut. Secara historis pusat-pusat kota di Indonesia dapat dibedakan sebagai pusat kota lama dan pusat kota baru, pusat kota lama dicirikan oleh struktur kota kolonial, baik sebagai pusat pemerintahan karesidenan atau asisten residen atau kabubupaten (Tondobala, 2012:85). Kota Padang terdapat kota lama Padang yang dicirikan dengan struktur Kolonial Belanda. Dengan menjaga keaslian kawasan kolonial perlu adanya peraturan. Pemerintah Kota Padang mengeluarkan Keputusan Walikota Padang Nomor 60 Tahun 2017. Kebijakan tersebut di implementasikan menjadi peraturan pariwisata, yang mana kawasan tersebut identik dengan bangunan cagar budayanya yang berada ditepian sungai Batang Arau, bangunan tersebut harus terjaga keasliannya jadi untuk menjaga keasliaslian bangunan cagar budaya maka Disparbud memberikan surat himbauan atau peringatan kepada pemilik gedung untuk dapat merawat bangunan milik mereka. Untuk saat ini peran peran Disparbud untuk mengatur bangunan cagar biasaya pada destinasi wisata kota tua untuk saat ini masih sebatas himbauan-himbauan kepada pemilik pemilik bangunan.

\section{Perencanaan Pariwisata}

Disparbud merupakan instansi pemerintah yang memiliki tanggung jawab dalam melakukan pengembangan pariwisata di daerahnya. Pengembangan Batang Arau sebagai destinasi wisata kota tua tidak terlepas dari peran pemerintah yang memiliki tugas dalam sebuah perencanaan pariwisata. Ada beberapa aspek yang diperlukan dalam perencanaan kepariwisataan diantaranya adalah perencanaan wisatawan, perencanaan daya tarik wisata, perencanaan fasilitas serta perencanaan promosi (Muljadi dan Warman, 2014:80). Berdasarkan hasil yang diperoleh peneliti di lapangan dapat diketahui bahwa Disparbud 
memiliki perencanaan pariwisata yaitu membentuk suatu kawasan wisata terpadu, penyediaan sarana dan prasarana kepariwisataan di Batang Arau.

Yoety dalam Tondobala (2012: 88) menyatakan baik prasarana dan sarana kepariwisataan sesungguhnya merupakan tourism supply yang perlu disiapkan atau disediakan bila hendak mengembangkan pariwisata. Berdasarkan hal tersebut diketahui bahwa untuk memenuhi kebutuhan wisatawan Pemerintah Kota Padang melalui Dinas PUPR sedang merencanakan adanya penambahan pembangunan pedistrian berupa trotoar dan lampu jalan yang ada di Batang Arau, karena masih ada sebagian yang masih belum terselesaikan, maka adanya penambahan pedestrian lagi di beberapa titik di kawasan Batang Arau.

Menurut Husen (2013) daya tarik wisata dibedakan menjadi 3 jenis, yaitu wisata alam, wisata budaya serta wisata buatan manusia. Batang Arau termasuk ke dalam jenis daya tarik wisata sejarah karena mengandalkan bangunan sejarah dan peradaban sejarah Belanda serta pusat perkotaan lama Padang dahulunya dan juga adanya keindangan sungai Batang Arau dengan keindahan kapal-kapal yang terparkir disepanjang sungai Batang Arau. Saat ini dapat diketahui bahwa Disparbud memiliki perencanaan untuk menambah daya tarik wisata berupa menjadikan muara Batang Arau sebagai pelabuhan kapal Marina. Dengan terwujudnya pembuatan kapal Marina tentu nantinya akan meningkatkan kunjungan wisatawan ke kota Padang baik itu wisatan lokal maupun mancanegara.

\section{Pembangunan Pariwisata}

Dinas Pariwisata dan Kebudayaan bekerjasama dengan Dinas Pekerjaan Umum Perumahan Rakyat sudah berupaya untuk mengembangkan Batang Arau melalui pembangunan sarana dan prasarana pariwisat. Pembangunan tersebut dinilai sudah cukup baik karena selain dapat digunakan wisatawan jufa dapat dimanfaatkan oleh masyarakat sekitar destinasi wisata. Untuk melakukan pelestarian bangunan cagar budaya yang terdapat di Batang Arau Dinas Pariwisata dan Kebudayaan melakukan pembangunan dalam hal sosialisasi dengan tujuan untuk meningkatkan kesadaran masyarakat, atau pemilik bangunan, atau wisatawan sehingga memiliki pengetahuan akan pentingnya bangunan cagar budaya atau bangunan sejarah yang terdapat di kota tua kawasan Batang Arau tersebut.

\section{Faktor-faktor yang mempengaruhi Batang Arau sebagai Destinasi Wisata Kota Tua Padang}

\section{Faktor Pendorong}

Menurut Undang-undang No. 10 Tahun 2009 menguraikan bahwa sebuah destinasi wisata merupakan kawasan geografis yang berada dalam satu atau lebih wilayah administratif yang di dalamnya terdapat daya tarik wisata, fasilitas umum, fasilitas pariwisata, serta masyarakat yang saling terkait dan melengkapi terwujudnya sebuah kepariwisataan pada suatu daerah. Mengacu pada pasal 1 Undang-Undang Nomor 1 tahun 2009 tentang Pariwisata dalam Frinaldi, dkk (2019: 50) yang dimaksud dengan daya tarik wisata adalah sesuatu yang unik, kenindahan, dan nilai dalam bentuk keanekaragaman alam, budaya dan kekayaan buatan manusia yang merupakan target atau wisata tujuan. Adapun faktor pendorong dalam mengembangkan Batang Arau sebagai destinasi wisata Kota Tua, sebagai berikut:

a. Daya tarik sejarah berupa bangunan sejarah masa Kolonial Belanda dengan menggambarkan keadaan Padang tempo dulu

b. Kaindahan alam yang indah berupa Gunung Padang, jembatan Sitinurbaya, Bukit GadoGado, dan Sungai Batang Arau yang dilengkapi dengan kapal-kapal tradisional dan kapal wisata. 


\section{Faktor Penghambat}

a. Ketersediaan anggaran

b. Ketersediaan sarana dan prasarana menjadikan ukuran optimal atau tidaknya pemerintah untuk melaksanakan tugas dan fungsinya sebagai pelayan masyarakat

c. Ketersediaan lahan parkir dan ketersediaan fasilitas umum seperti toilet.

d. Peran serta masyarakat berlum sepenuhnya mendukung program-program pemerintah.

\section{Upaya Pemerintah Kota Padang dalam mengembangkan Batang Arau sebagai destinasi wisata kota tua Padang.}

Adapun upaya yang dilakukan oleh Pemerintah Kota Padang khususnya Dinas Pariwisata dan Kebudayaan Kota Padang dalam mengatasi faktor penghambat dalam mengembangkan Batang Arau sebagai destinasi wisata kota tua yaitu dengan melakukan sosialisasi yang tujuannya untuk menambah pengetahuan masyarakat yang berada di objek wisata sehingga masyarakat akan sadar akan wisata yang terdapat di daerahnya.

\section{Kesimpulan}

Berdasarkan kajian di lapangan dan pembahasan terhadap fokus permasalahan mengenai Peran Pemerintah kota Padang dalam mengembangan Batang Arau sebagai destinasi wisata kota tua, Pemerintah Kota Padang melalui Disparbud memiliki peran pengembangan Batang Arau dengan membuat suatu kebijakan pariwisata yaitu Keputusan Walikota Padang No 154 Tahun 2019 dan Keputusan Walikota Padang No 60 Tahun 2017. Kemudian pemerintah membuat peraturan pariwisata dengan mengimplementasikan Keputusan Walikota No.60 Tahun 2017 dengan tujuan mengamankan aset kekayaan budaya dan peninggalan sejarah yang memiliki nilai penting bagi daerah, Disparbud hanya sekedar memberikan himbauan-himbauan kepada pemilik bangunan cagar budaya dan menjaga kawasan sejarah di Batang Arau. Selanjutnya pemerintah kota melalui Dinas Pariwisata dan Kebudayaan berperan dalam melakukan perencanaan dalam meningkatkan daya tarik wisata serta sarana dan prasarana untuk memenuhi kebutuhan wisatawan. Perencanaan tersebut meliputi penambahan daya tarik wisata berupa pengadaan pedestrian berupa trotoar, lampulampu jalan, taman, dan fasilias umum lainnya. Disparbud juga memiliki rencana untuk membentuk muara Batang Arau sebagai Pelabuhan Kapal Marina dan mewujudkan perencanaan kawasan wisata terpadu. Peranan pemerintah dalam melakukan pembangunan pada destinasi wisata kota tu di Batang Arau. Pembangunan yang sudah dilakukan saat ini masih berupa penambahan penerangan jalan dibeberapa titik di kawasan Batang Arau, perbaikan lampu jalan di beberapa titik di kawasan Batang Arau, serta pembangunan pedestrian berupa trotoar, jalan, kursi-kursi taman. Disparbud melakukan peranannya dalam pembangunan pariwisata berupa melakukan sosialisasi, pembinaan kelompok sadar wisata dikawasan Batang Arau dan membentuk komunitas Padang Heritage sebagai komunitas yang melestarikan kota tua Padang.. Adapun Faktor Pendorong nya yaitu adanya daya tarik wisata di Batang Arau sendiri yang daya tarik yang layak untuk dikembangkan karena memiliki potensi yang unik. Daya tarik yang ada di Batang Arau dapat dilihat dari sejarahnya yang berupa bangunan Cagar Budaya. Dan keindahan alamnya yang berupa keindahan kapal-kapal wisata, sungai, dan Gunung Padang. Dengan adanya daya tarik tersebut menjadi modal untuk mendorong adanya pengembangan Batang Arau sebagai destinasi wisata kota tua. berpotensi untuk dikembangkan menjadi destinasi wisata yang lebih baik lagi. Faktor penghambat yaitu ketersediaan anggaran, peran masyarakat yang belum sepenuhnya mendukung program dari 
pemerintah. Upaya Pemerintah Kota Padang dalam mengatasi faktor penghambat yaitu dengan melakukan sosialisasi yang tujuannya untuk menambah pengetahuan masyarakat yang berada di objek wisata sehingga masyarakat akan sadar akan wisata yang terdapat di daerahnya.

\section{Daftar Pustaka}

Afandi, Achmad, Sunarti dan Hakim, Luchman. (2017). Penan Pemerintah Daerah dalam Pengembangan Destinasi Wisata Bahari Pulai Gili Noko Kabupaten Gresik. Jurnal Administrasi Bisnis (JAB). Vol. 49 No.1.

Ashworth G.J. dan Tunbridge, J.E. (1990): The Tourist-Historic City, John Wiley\&Sons, England.

Asnan, Phill Gusti. (2015). Cagar Budaya Dimata Publik (Edisi II). Batusangkar: Balai Pelestarian Cagar Budaya Provinsi Sumatera Barat, Riau, dan Kepulauan Riau.

Lexy, J Moleong. (2005). Metodologi Penelitian Kualitatif. Bandung: PT Remaja Rosdakarya.

Pemerintah Kota Padang. (2006). Evaluasi Penetapan Kawasan Konservasi dan Bangunan Cagar Budaya di Kota Padang. Dinas Tata Ruang dan Tata Bangunan PUPR.

Peraturan Walikota Padang Nomor 03 Tahun 1998 tentang Penetapan Bangunan Cagar Budaya dan Kawasan Bersejarah di Kotamadya Padang.

Peraturan Walikota Padang Provinsi Sumatera Barat Nomor 60 Tahun 2017 tentang Pedoman Penyelenggaraan Cagar Budaya.

Simamora, Rotua Kristin dan Sinaga, Rudi Salam. (2016). Peran Pemerintah Daerah dalam Pengembangan Pariwisata Alam dan Budaya di Kabupaten Tapanuli Utara. Jurnal Ilmu Pemerintah dan Sosial Politik UMA. Vol 4 No. 1 Hal 79-96.

Sugiyono. (2011). Metode Penelitian Administrasi Metode R\&B. Bandung: Alfabeta.

Tondobala, Linda. (2012). Kelayakan Pusat Kota Manado sebagai Destinasi Pariwisata. Jurnal Edia Matrasain. Vol 8 No 3.

Yulia, Refni dkk. (2017). "Revitalisasi Kawasan Kota Tua Padang sebagai Salah Satu Alternatif Wisata Sejarah di Kota Padang". Jurnal Bakaba. Volume 6, Nomor 2, JuniDesember 2017. 